\title{
MODAL INVESTASI AWAL DAN PERSEPSI RISIKO DALAM KEPUTUSAN BERINVESTASI
}

\author{
Ni Nyoman Sri Rahayu Trisna Dewia, ${ }^{*}$, Komang Fridagustina \\ Adnantarab, Gde Herry Sugiarto Asanac \\ a,b,c STIE Triatma Mulya, Jl. Kubu Gunung, Tegal Jaya, Badung, Bali \\ *(rahayutrisna333@gmail.com)
}

\begin{abstract}
ABSTRAK
Pasar modal merupakan istilah yang masih asing di kalangan masyarakat luas. Pemerintah melalui BEI mulai melakukan edukasi dengan menggandeng perguruan tinggi untuk memberikan wawasan kepada mahasiswa mengenai pasar modal, karena mahasiswa merupakan calon investor muda yang lebih terbuka wawasannya mengenai hal-hal yang baru, termasuk pasar modal. Dalam memutuskan berivestasi di pasar modal, banyak faktor yang dapat mempengaruhi, seperti persepsi atas risiko dan modal investasi minimal. Penelitian ini bertujuan untuk mengetahui pengaruh persepsi atas risiko dan modal investasi minimal terhadap minat berinvestasi di pasar modal dengan menggunakan mahasiswa sebagai sampel penelitian. Metode yang digunakan untuk menganalisis data dalam penelitian ini adalah analisis regresi linier berganda. Hasil penelitian menunjukkan bahwa persepsi atas risiko dan modal investasi minimal berpengaruh terhadap minat berinvestasi di pasar modal.
\end{abstract}

Kata kunci: terdiri dari 3-5 kata/terminologi

\section{ABSTRACT}

Capital market is a term that is still foreign to the community. The government through IDX began to educate by cooperating with universities to give students education about capital market, because students are young prospective investors who are more open to their insights about new things, including the capital market. In deciding to invest in the capital market, many factors can affect, such as perceptions of risk and minimal investment capital. This study aims to determine the effect of perceptions on risk and minimum investment capital on the interest of investing in the capital market by using students as research samples. The method used to analyze the data in this study is multiple linear regression analysis. The results showed that the perception of risk and

Keywords: terdiri dari 3-5 kata/terminologi

\section{PENDAHULUAN}

Pasar modal merupakan istilah yang masih asing di kalangan masyarakat luas. Pasar modal menawarkan beberapa produk yang dapat dipilih oleh masyarakat untuk berinvestasi, antara lain saham, obligasi, dan lain-lain. Namun dewasa 
ini investasi di pasar modal masih menjadi hal yang dianggap berbahaya bagi masyarakat, khususnya bagi masyarakat yang belum mendapatkan edukasi mengenai produk-produk di pasar modal. Berinvestasi di pasar modal hampir sama dengan melakukan simpanan di bank, hanya saja berinvestasi di pasar modal memberikan risiko bagi para calon investor. Namun, semakin besar risiko yang dihadapi, pengembalian atas investasi yang diperoleh juga semakin tinggi. Hal ini yang belum diketahui dengan baik oleh masyarakat umum. Padahal jika mau mencoba memulai berinvestasi di pasar modal dan belajar untuk melakukan analisa terhadap produkproduk pilihan di pasar modal, keuntungan yang diperoleh bisa 100\% lebih banyak daripada bunga simpanan yang diperoleh dengan menyimpan uang di bank. Bahkan Pemerintah Indonesia sudah mulai menggalakkan program investasi melalui pasar modal dalam masyarakat dengan memberikan kemudahan-kemudahan masyarakat umum untuk dapat memulai berinvestasi, yaitu dengan menurunkan saldo minimal pembukaan rekening sekuritas. Hal ini diharapkan dapat menarik minat masyarakat umum, termasuk mahasiswa dan pelajar yang notabene masih belum memiliki nominal uang yang banyak.

Di Indonesia, sangat banyak investor asing yang menanamkan modalnya. Hal ini akan membawa dampak yang positif dalam jangka pendek, namun akan memberikan dampak yang negatif dalam jangka panjang. Karena dalam jangka panjang yang diuntungkan adalah investor asing, bukan bangsa Indonesia sendiri, karena investor asing akan mendapatkan bunga atas investasi yang telah dilakukan, sementara penduduk Indonesia hanya mengeluarkan uang untuk mengkonsumsi barang. Hal ini disebabkan oleh investasi, khususnya investasi di pasar modal, masih belum menarik bagi masyarakat Indonesia. Padahal pasar modal di Indonesia sangat menjanjikan, mengingat banyak investor asing yang malah memilih untuk berinvestasi di Indonesia daripada di negaranya sendiri.

Dikutip dari kompas.com, lambatnya pertumbuhan investor $\mathrm{di}$ BEI dapat disebabkan oleh beberapa hal, seperti masyarakat instan dan masyarakat konsumtif. Masyarakat hanya melihat keuntungan dalam jangka pendek yang bisa diperoleh. Dalam berinvestasi, masyarakat mempunyai keinginan untuk dapat memperoleh keuntungan secara 
instan. Pola pikir inilah yang seharusnya ditinggalkan oleh masyarakat. Keuntungan cepat adalah sebuah pemikiran yang membuat masyarakat kita sulit diajak berinvestasi pada pasar modal yang keuntungannya memerlukan waktu dan tidak dapat dipastikan nilainya saat pertama berinvestasi. Masyarakat Indonesia juga terkenal sebagai masyarakat yang konsumtif, sehingga ,asyarakat Indonesia menjadi target penjualan barangbarang konsumtif dari seluruh dunia. Dengan tidak memiliki pengendalian diri, masyarakat Indonesia lebih suka mengkonsumsi daripada berinvestasi demi masa depannya. Pertumbuhan investor pasar modal di Indonesia memang memerlukan waktu yang panjang karena proses terjadi bukan dari luar melainkan dari diri sendiri.

Masih banyak masyarakat yang beranggapan bahwa investasi di pasar modal adalah permainan judi. Ini merupakan suatu tantangan bagi Pemerintah melalui Bursa Efek Indonesia agar bisa menghilangkan anggapan masyarakat tersebut. Bursa Efek Indonesia mulai secara rutin mengadakan sekolah pasar modal yang dapat diikuti oleh masyarakat umum tanpa terkecuali, dengan tujuan untuk memperkenalkan dan mengedukasi masyarakat mengenai pengetahuan tentang pasar modal.
Edukasi yang diberikan diharapkan dapat memberikan pemahaman kepada masyarakat sehingga mereka tertarik untuk memulai berinvestasi di pasar modal. KSEI telah mencatat peningkatan kinerja operasional sampai pertengahan tahun 2017, yaitu jumlah single Investor Identification (SID) yang meningkat 14,7\% dari 894.116 per tahun 2016 menjadi 1.025.414 per Juli tahun 2017 (ksei.co.id). Edukasi juga mulai dilakukan dengan menggandeng perguruan tinggi untuk memberikan wawasan kepada mahasiswa mengenai pasar modal, karena mahasiswa merupakan calon investor muda yang lebih terbuka wawasannya mengenai hal-hal yang baru, termasuk pasar modal.

Minat mahasiswa dalam berinvestasi di pasar modal dapat dipengaruhi oleh beberapa faktor, seperti persepsi atas risiko dan modal investasi minimal. Persepsi atas risiko yang dimiliki oleh masing-masing orang berbeda-beda, bahkan mahasiswa yang sudah dibekali pengetahuan mengenai pasar modal juga memiliki persepsi atas risiko yang berbeda-beda. Sebagian mahasiswa berani mengambil risiko, dan sebagian mahasiswa tidak berani mengambil risiko. Berinvestasi di pasar modal tidak bisa terlepas dari risiko. Semakin tinggi risiko yang 
berani diambil maka kemungkinan keuntungan yang diperoleh juga akan semakin tinggi. Mahasiswa yang berani mengambil risiko tentu saja akan lebih berminat untuk berinvestasi di pasar modal, karena pasar modal dapat menawarkan pengembalian yang lebih tinggi. Malik (2017) menyatakan semakin tinggi risiko maka minat investor untuk berinvestasi semakin meningkat.

Mahasiswa merupakan calon investor yang masih kurang mapan dalam hal finansial, karena sebagian besar mahasiswa belum bisa menghasilkan uang sendiri. Faktor jumlah modal investasi minimal untuk dapat memulai berinvestasi di pasar modal tentu saja menjadi pertimbangan penting bagi mahasiswa. Sebelumnya investor hanya bisa berinvestasi dengan modal jutaan rupiah, tetapi sekarang dengan modal investasi minimal Rp100.000 calon investor sudah bisa membuka rekening sekuritas dan memulai bertransaksi di pasar modal. Perusahaan-perusahaan yang terdaftar di Bursa Efek Indonesia juga sangat banyak yang menawarkan saham dengan harga yang murah, sehingga dengan modal Rp100.000 calon investor sudah bisa langsung melakukan transaksi saham. Hasil penelitian Nisa dan Sulaika (2017) menyatakan bahwa modal minimal yang ditetapkan memiliki pengaruh terhadap minat mahasiswa untuk berinvestasi di pasar modal.

Penelitian mengenai minat investasi di pasar modal masih sangat sedikit dilakukan, padahal penting untuk melakukan penelitian di bidang tersebut mengingat investasi yang dilakukan oleh masyarakat dapat mempengaruhi GDP yang dihasilkan oleh Negara. Dalam ekonomi makro, investasi merupakan salah satu komponen dari pendapatan nasional, Produk Domestik Bruto (PDB) atau Gross Domestic Product (GDP). Hal ini berarti investasi mempunyai peran yang besar dalam pendapatan nasional suatu negara. GDP terdiri dari konsumsi, investasi, pembelian oleh pemerintah, dan ekspor atau impor. Investasi mempunyai hubungan yang positif dengan GDP yang dihasilkan suatu negara. Jika investasi dalam suatu Negara naik, maka GDP cenderung juga akan naik. Berdasarkan latar belakang tersebut maka rumusan masalah yang diajukan dalam penelitian ini adalah:

1. Apakah persepsi atas risiko berpengaruh terhadap minat berinvestasi di pasar modal?

2. Apakah modal investasi minimal berpengaruh terhadap minat berinvestasi di pasar modal? 
Berdasarkan rumusan masalah yang telah diuraikan sebelumnya, penelitian ini bertujuan untuk:

1. Mengetahui pengaruh persepsi atas risiko terhadap minat berinvestasi di pasar modal

2. Mengetahui pengaruh modal investasi minimal terhadap minat berinvestasi di pasar modal

\section{TELAAH LITERATUR DAN PERUMUSAN HIPOTESIS}

\section{Teori Pengambilan Keputusan}

Pengambilan

keputusan seringkali disamakan dengan proses berpikir, mengatur, dan memecahkan masalah.

Dalam

setting organisasional, pengambilan keputusan seringkali didefinisikan sebagai proses memilih diantara berbagai alternatif tindakan yang mempengaruhi masa depan. Menurut Kahneman dan Tversky (1979) keputusan didefinisikan sebagai tindakan atau opsi diantara yang harus dipilih, konsekuensi dari tindakan dan probabilitas kondisional atau kontinjensi yang berhubungan dengan hasil dari tindakan. Stoner, et al. (1995) menyebutkan bahwa pengambilan keputusan adalah proses mengidentifikasi dan memilih serangkaian tindakan untuk menghadapi masalah tertentu atau mengambil keuntungan dari suatu kesempatan. Dalam membuat keputusan banyak diantaranya yang menyangkut peristiwa pada masa depan yang sulit diramalkan.

\section{Pasar Modal}

Menurut Jogiyanto (2010) pasar modal merupakan tempat bertemu antara pembeli dan penjual dengan risiko untung dan rugi. Pasar modal juga dinyatakan sebagai sarana perusahaan untuk meningkatkan kebutuhan dana jangka panjang dengan menjual saham atau mengeluarkan obligasi. Pengertian pasar modal secara umum adalah suatu sistem keuangan yang terorganisir, termasuk di dalamnya adalah bank-bank komersial dan semua lembaga perantara di bidang keuangan, serta keseluruhan suratsurat berharga yang beredar. Dalam arti sempit, pasar modal adalah suatu pasar (tempat, berupa gedung) yang disiapkan guna memperdagangkan saham-saham, obligasi-obligasi dan jenis surat berharga lainnya dengan memakai jasa para perantara efek (Sunariyah, 2004).

Menurut Herve dan Yao (2011), pasar modal merupakan pasar untuk pinjaman dana jangka panjang yang digunakan oleh industri dan perdagangan terutama untuk investasi tetap. Menurut UndangUndang Pasar Modal No.8 tahun 
1995, pasar modal adalah suatu kegiatan yang bersangkutan dengan penawaran umum dan perdagangan efek, perusahaan publik yang berkaitan dengan efek yang diterbitkannya, serta lembaga dan profesi yang berkaitan dengan efek. Pendapat lain dari Ravichandran et al (2005), yang mengatakan bahwa pasar modal merupakan salah satu investasi yang populer karena keuntungan yang diharapkan tinggi.

Berdasarkan pengertian di atas, dapat disimpulkan bahwa pasar modal adalah tempat pertemuan antara penawaran dan permintaan surat berharga atau tempat pertemuan antara pihak yang memiliki kelebihan dana dengan pihak yang membutuhkan dana dengan jalan memperjualbelikan surat-surat berharga.

\section{Peranan Pasar Modal}

Fungsi yang paling mendasar bagi pasar modal adalah untuk mengalokasikan sumber daya perusahaan dengan prospek jangka panjang yang paling menjanjikan (Rappaport, 2005). Pasar modal merupakan sarana perusahaan untuk meningkatkan kebutuhan dana jangka panjang dengan menjual saham atau mengeluarkan obligasi (Jogiyanto, 2010). Menurut Sunariyah (2004), seberapa besar peranan pasar modal pada suatu Negara dapat dilihat dari lima segi sebagai berikut:

1) Sebagai fasilitas melakukan interaksi antara pembeli dengan penjual untuk menentukan harga saham atau surat berharga yang diperjualbelikan.

2) Pasar modal memberi kesempatan kepada para pemodal untuk menentukan hasil (return) yang diharapkan.

3) Pasar modal memberi kesempatan kepada investor untuk menjual kembali saham yang dimilikinya atau surat berharga lainnya.

4) Pasar modal menciptakan kesempatan kepada masyarakat untuk berpartisipasi dalam perkembangan suatu perekonomian.

5) Pasar modal mengurangi biaya informasi dan transaksi surat berharga.

\section{Jenis Instrumen Pasar Modal}

Menurut Anoraga dan Pakarti (2003), instrumen pasar modal adalah semua surat-surat berharga (securities) yang diperdagangkan di bursa. Instrumen pasar modal ini umumnya bersifat jangka panjang. Sekuritas yang diperdagangkan adalah: 


\section{1) Saham}

Menurut Darmadji dan Fakhruddin (2001), saham adalah tanda penyertaan atau pemilikan seseorang atau badan dalam suatu perusahaan atau perseroan terbatas. Wujud saham adalah selembar kertas yang menerangkan bahwa pemilik kertas adalah pemilik perusahaan yang menerbitkan surat berharga tersebut. Menurut Anoraga dan Pakarti (2003), manfaat yang diperoleh dari investasi saham yaitu:

a) Dividen, bagian dari keuntungan perusahaan yang dibagikan kepada pemilik saham.

b) Capital gain, adalah keuntungan yang diperoleh dari selisih jual dengan harga belinya.

c) Manfaat non-finansial yaitu timbulnya kebanggaan dan kekuasaan memperoleh hak suara dalam menentukan jalannya perusahaan.

Jenis saham yang dikenal di bursa, yang diperdagangkan yaitu saham biasa (common stock) dan saham preferen (preferred stock). Saham biasa adalah saham yang tidak memperoleh hak istimewa. Pemegang saham biasa mempunyai hak untuk memperoleh dividen sepanjang perseroan memperoleh keuntungan (Anoraga dan Pakarti,
2003). Saham preferen adalah saham yang diberikan atas hak untuk mendapatkan dividen dan/atau bagian kekayaan pada saat perusahaan dilikuidasi terlebih dahulu dari saham biasa, disamping itu mempunyai preferensi untuk mengajukan usul pencalonan direksi/komisaris (Anoraga dan Pakarti, 2003).

\section{2) Obligasi}

Obligasi pada dasarnya merupakan surat pengakuan hutang atas pinjaman yang diterima oleh perusahaan penerbit obligasi dari masyarakat pemodal (Sunariyah, 2004). Jangka waktu obligasi telah ditetapkan dan disertai dengan pemberian imbalan bunga yang jumlah dan saat pembayarannya telah ditetapkan dalam perjanjian. Menurut Anoraga dan Pakarti (2003), obligasi adalah surat tanda peminjaman uang yang mempunyai jangka waktu tertentu, biasanya lebih dari satu tahun. Dengan demikian, pada hakikatnya obligasi adalah suatu tagihan uang atau beban/ tanggungan pihak yang menerbitkan/ mengeluarkan obligasi tersebut, pemegang/ pembeli obligasi memperoleh keuntungan berupa tingkat bunga tertentu yang dibayarkan oleh perusahaan yang mengeluarkan obligasi tersebut. 


\section{3) Waran}

Waran merupakan opsi jangka panjang yang memberikan hak kepada pemegangnya untuk membeli saham atas nama dengan harga tertentu. Masa hidup waran dimulai dari tanggal waran tersebut dicatatkan di bursa efek, sampai dengan tanggal terakhir pelaksanaan penebusan (redemption) waran (Anoraga dan Pakarti, 2003).

\section{4) Right (Sertifikat Bukti Right)}

Sertifikat bukti right dapat didefinisikan sebagai efek yang memberikan hak kepada pemegang saham lama untuk membeli saham baru yang akan dikeluarkan oleh emiten pada proporsi dan harga tertentu (Anoraga dan Pakarti, 2003).

\section{5) Reksa dana}

Menurut Sunariyah (2004), reksa dana merupakan kumpulan saham-saham, obligasi-obligasi atau sekuritas lainnya yang dimiliki oleh sekelompok pemodal dan dikelola oleh perusahaan investasi profesional. Dana yang diinvestasikan pada reksa dana dari pemodal akan disatukan dengan dana yang berasal dari pemodal lainnya untuk menciptakan kekuatan membeli yang jauh lebih besar dibanding mereka harus melakukan investasi sendiri.

\section{Minat Berinvestasi di Pasar Modal}

Kamus Besar Bahasa Indonesia mendefinisikan minat sebagai keinginan untuk memperhatikan atau melakukan sesuatu. Fahriani (2012) menyatakan minat adalah kecenderungan hati yang tinggi terhadap sesuatu. Minat merupakan salah satu aspek afektif yang memiliki peran besar dalam kehidupan seseorang. Aspek afektif mengidentifikasi dimensi - dimensi dalam perasaan dari kesadaran emosi, disposisi, dan keinginan yang mempengaruhi pikiran dan tindakan seseorang.

Terdapat beberapa hal yang perlu diperhatikan dalam minat seseoang, antara lain (Fahriani, 2012):

1) Minat dianggap sebagai perantara faktor-faktor motivasional yang mempunyai dampak pada suatu perilaku.

2) Minat menunjukkan seberapa keras seseorang berani mencoba melakukan sesuatu.

3) Minat menunjukkan seberapa banyak upaya yang direncanakan seseorang untuk melakukan sesuatu

Seseorang yang memiliki minat terhadap sesuatu, cenderung untuk memberikan perhatian yang lebih besar terhadap hal tersebut, namun sebaliknya seseorang tidak akan 
memiliki minat terhadap sesustu jika tidak memiliki rasa senang atau perhatian yang besar terhadap hal tersebut.

\section{Return dan Risiko Investasi}

Seseorang yang menginvestasikan dananya ke dalam saham akan mengharapkan memperoleh return (pengembalian). Jogiyanto (2010) menyatakan return merupakan hasil yang diperoleh dari investasi yang dapat berupa return realisasian (realized return) yang telah terjadi atau return ekspektasian (expected return) yang belum terjadi tetapi diharapkan akan terjadi di masa datang. Perbedaan antara return ekspektasian dan return realisasian merupakan pengukur risiko yang harus dipertimbangkan oleh investor dalam proses investasi (Tandelilin, 2003). Suharli (2005) menyatakan return saham adalah keuntungan yang diperoleh dari kepemilikan saham investor atas investasi yang dilakukannya, yang terdiri dari dividen dan capital gain/loss. Dalam pasar saham tidak selalu menjanjikan suatu return yang pasti bagi investor. Untuk mendapat return tertentu seorang investor juga harus memperhatikan risiko yang akan ditanggung. Risiko merupakan kemungkinan perbedaan antara return aktual yang diterima dengan return yang diharapkan, yang terdiri dari dua jenis yaitu risiko umum (general risk) yang merupakan risiko yang berkaitan dengan perubahan yang terjadi di pasar secara keseluruhan dan risiko spesifik (risiko perusahaan) adalah risiko yang tidak berkaitan dengan perubahan pasar secara keseluruhan (Utomo, 2007). Persepsi terhadap risiko memainkan peran penting dalam perilaku manusia khususnya terkait pengambilan keputusan dalam keadaan tidak pasti. (Rosyidah, 2013). Investor mengalami risiko saat investor tidak mengetahui dengan pasti hasil investasi yang dilakukannya (Malik, 2017). Kusmawati(2011) menyatakan investasi di pasar modal tidak dapat dipisahkan antara return dan tingkat risiko, kecuali jika investasi tersebut diproteksi oleh pemerintah/institusi yang berwenang, seperti praktekpraktek bisnis pada masa orde baru.

\section{Modal Investasi Minimal}

BEI telah menerbitkan kebijakan untuk memberikan kemudahan kepada para calon investor pada 6 Januari 2014, yaitu jumlah minimal pembelian saham dari suatu emiten (perusahaan yang menjual sahamnya ke public adalah sebanyak 1 lot (100 lembar saham). Dengan adanya kebijakan dari BEI tersebut, maka 
dengan Rp100.000 calon investor sudah bisa membuka rekening sekuritas dan dapat melakukan transaksi di pasar modal.

\section{Hipotesis Penelitian}

Tandio dan Widanaputra (2016) menyatakan preferensi investor dalam hal investasi, erat kaitannya dengan pertimbangan terhadap return dan risiko investasi. Setiap investor memiliki kemampuan menanggung risiko yang berbeda-beda, namun mereka mengharapkan return yang sesuai. Dalam investasi, tidak cukup jika hanya mempertimbangkan faktor return saja. Investor juga harus mempertimbangkan faktor risiko karena pertimbangan suatu investasi merupakan trade-off dari kedua faktor tersebut. Return dan risiko mempunyai hubungan yang positif, semakin besar risiko yang harus ditanggung, semakin besar return yang harus dikompensasikan (Jogiyanto, 2010).

Pemahaman mengenai investasi sangat diperlukan oleh seseorang untuk melakukan investasi. Apalagi mengenai dasar-dasar investasi termasuk risiko yang diperoleh ketika melakukan investasi sehingga dapat digunakan sebagai pengambilan keputusan untuk melakukan investasi (Nisa dan Sulaika, 2017, Merawati dan Putra, 2015). Persepsi terhadap risiko memainkan peran penting dalam perilaku manusia khususnya terkait pengambilan keputusan dalam keadaan tidak pasti (Rosyidah, 2013). Malik (2017) menyatakan semakin tinggi risiko maka minat investor untuk berinvestasi semakin meningkat. Namun hasil penelitian Tandio dan Widanaputra (2016) menemukan bahwa persepsi mengenai risiko tidak dapat mempengaruhi minat mahasiswa untuk berinvestasi. Hasil penelitian Rosyidah (2013) juga menemukan bahwa Persepsi risiko tidak berpengaruh terhadap pengambilan keputusan investasi.

Saat memulai untuk berinvestasi, mahasiswa khususnya, akan berfikir mengenai modal awal yang harus dikeluarkan mengingat sebagian besar mahasiswa belum memiliki pekerjaan. Semakin kecil modal awal investasi yang diberikan maka akan meningkatkan minat mahasiswa untuk mencoba memulai investasi. Hasil penelitian Nisa dan Sulaika (2017) menyatakan bahwa modal minimal yang ditetapkan memiliki pengaruh terhadap minat mahasiswa untuk berinvestasi di pasar modal. Sedangkan Raditya, dkk (2014) menyatakan modal investasi minimal tidak memiliki pengaruh terhadap minat investasi. 
Berdasarkan uraian tersebut, hipotesis yang diajukan dalam penelitian ini adalah:

$\begin{aligned} \text { H1: } & \text { Persepsi atas risiko } \\ & \text { berpengaruh terhadap minat } \\ & \text { berinvestasi di pasar modal }\end{aligned}$

H2: Modal investasi minimal berpengaruh terhadap minat berinvestasi di pasar modal

Berdasarkan hipotesis yang telah diajukan, dapat digambarkan model penelitian seperti pada Gambar 1 .

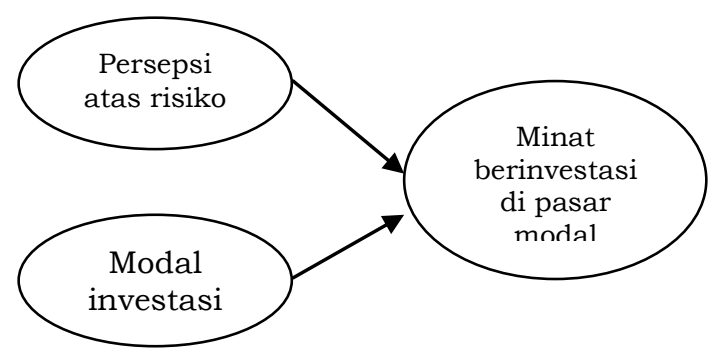

Gambar 1. Model Penelitian

\section{METODE}

\section{Rancangan Penelitian}

Tahapan penelitian adalah rencana dari struktur penelitian yang mengarahkan proses dan hasil riset sedapat mungkin menjadi valid, objektif, efisien, dan efektif. Penelitian ini bertujuan untuk mengetahui pengaruh persepsi atas risiko dan modal investasi minimal secara parsial terhadap minat berinvestasi di pasar modal. Populasi yang digunakan dalam penelitian ini adalah mahasiswa Jurusan Akuntansi STIE Triatma Mulya, karena diasumsikan mereka telah memiliki pengetahuan mengenai pasar modal, baik melalui mata kuliah yang telah diperoleh selama perkuliahan, maupun melalui seminar pasar modal yang diselenggarakan secara internal. Cara pengambilan sampel dilakukan dengan teknik sampling jenuh. Berdasarkan latar belakang dilakukannya penelitian, maka peneliti dapat merumuskan permasalahan yang akan diteliti, kemudian membangun hipotesis berdasarkan kajian teori dan penelitian sebelumnya. Untuk mengetahui apakah hipotesis diterima atau ditolak, peneliti menggunakan regresi linier berganda untuk menganalisis data-data yang telah dikumpulkan. Hasil analisis kemudian diinterpretasikan dan kemudian dibuatkan simpulan dan diberi saran mengenai keterbatasan penelitian.

\section{Sasaran Penelitian}

Populasi dalam penelitian ini adalah mahasiswa Jurusan Akuntansi STIE Triatma Mulya yang telah memperoleh mata kuliah teori pasar modal atau telah mengikuti seminar pasar modal, yaitu sejumlah 81 mahasiswa. Metode pengambilan sampel dilakukan dengan teknik sampling jenuh, dimana semua 
populasi digunakan sebagai sampel dalam penelitian.

Pemahaman dasar tentang investasi yang meliputi jenis investasi, return dan risiko investasi memudahkan seseorang untuk mengambil keputusan berinvestasi. Pengetahuan yang memadai sangat diperlukan untuk menghindari terjadinya kerugian saat berinvestasi di pasar modal, seperti pada instrumen investasi saham (Merawati dan Putra, 2015). Oleh karena itu sampel dalam penelitian ini digunakan mahasiswa akuntansi yang telah memperoleh mata kuliah pasar modal dan juga telah mengikuti seminar mengenai pasar modal, sehingga mereka telah memiliki pengetahuan yang cukup mengenai investasi di pasar modal.

\section{Metode Pengumpulan Data}

Metode pengumpulan data yang digunakan dalam penelitian ini adalah:

1) Observasi nonpartisipan, yaitu teknik pengumpulan data dimana peneliti tidak terlibat dan hanya sebagai pengamat independen (Sugiyono, 2009:204). Peneliti mengamati, mengutip, mencatat, serta mengumpulkan data dari STIE Triatma Mulya.
2) Wawancara, yaitu metode pengumpulan data dengan cara melakukan tanya jawab dengan Kepala Bagian Kemahasiswaan mengenai halhal yang terkait dengan responden penelitian, seperti jumlah mahasiswa Jurusan Akuntansi STIE Triatma Mulya.

3) Kuesioner, yaitu metode pengumpulan data yang dilakukan dengan cara memberi seperangkat pertanyaan atau pernyataan tertulis kepada responden untuk dijawab (Sugiyono, 2009). Kuesioner yang disebarkan berupa daftar pertanyaan dan pernyataan tertulis kepada responden mengenai pengaruh persepsi atas risiko dan modal investasi minimal terhadap minat berinvestasi mahasiswa. Dalam penelitian ini digunakan skala likert dengan rentang 1 sampai 4 dengan alasan untuk menghindari jawaban-jawaban responden yang ambigu (bermakna ganda) karena adanya pernyataan "ragu-ragu" atau "netral" yang timbul dari nilai tengah (misal nilai 3 jika menggunakan 5 skala likert). Dalam skala likert variabelvariabel yang diukur 
dijabarkan ke dalam indikator variabel. Indikator tersebut dijadikan dasar untuk menyusun instrumen yang dapat berupa pernyataan. Jawaban setiap instrumen mempunyai gradasi dari sangat positif sampai dengan sangat negatif, dan responden diminta untuk memberikan respon terhadap setiap pernyataan dengan memilih satu diantara pilihan yang bersifat jenjang.

\section{Identifikasi Variabel}

Variabel-variabel yang akan dianalisis dapat dikelompokkan sebagai berikut:

1) Variabel dependen, yaitu variabel yang dipengaruhi atau yang menjadi akibat, karena adanya variabel independen (Sugiyono, 2009). Variabel dependen dalam penelitian ini adalah minat berinvestasi di pasar modal yang diukur dengan menggunakan 7 item pernyataan (Alleyne, 2011).

2) Variabel independen, yaitu variabel yang memengaruhi atau yang menjadi sebab perubahannya atau timbulnya variabel dependen (Sugiyono, 2009). Variabel independen dalam penelitian ini adalah persepsi atas risiko yang diukur dengan 5 item pernyataan (Rosyidah, 2013) dan modal investasi minimal yang diukur dengan 4 item pernyataan (Riyadi, 2016).

\section{Teknik Analisis Data}

Hipotesis dalam penelitian ini diuji dengan menggunakan analisis regresi linier berganda. Sebelum menguji dan menganalisis data dengan menggunakan model analisis regresi linier berganda, maka terlebih dulu dilakukan pengujian asumsi klasik agar dapat dijadikan alat estimasi yang tidak bias jika telah memenuhi persyaratan BLUE (Best Linier Unbiased Estimator) sehingga hasil perhitungan dapat diinterpretasikan dengan efisien dan akurat. Bagian ini memuat tentang rancangan atau desain penelitian, sasaran penelitian (populasi, sampel, informan atau subjek penelitian), teknik pengembangan instrumen dan metode pengumpulan data, pengukuran dan pendefinisian variabel serta teknik analisis data.

\section{HASIL DAN PEMBAHASAN}

Pengujian Instrumen Penelitian

Uji Validitas dalam penelitian ini menggunakan korelasi product moment. Instrumen dinyatakan valid bila koefisien korelasi $(r) \geq 0,3$ dan bila $(\mathrm{r})<0,3$ tidak valid. Hasil Uji Validitas 


\begin{abstract}
menunjukkan semua butir pernyataan kuesioner dalam penelitian ini valid karena masingmasing butir pernyataan dari variabel persepsi atas resiko, modal minimal investasi dan minat berinvestasi memiliki nilai koefisien korelasi $>0,3$. Pengukuran reliabilitas dalam penelitian ini mempergunakan formula koefisien Cronchbach Alpha. Instrumen dikatakan reliabel bila ri>0,6, tidak reliabel jika ri<0,6. Uji Reliabilitas menunjukkan bahwa instrumen yang digunakan dalam penelitian ini adalah reliabel karena nilai cronchbach alpha masingmasing variabel dalam penelitian ini > 0,6 .
\end{abstract}

\section{Uji Asumsi Klasik}

Hasil uji normalitas Kolmogorov Smirnov Test pada Tabel 2 menunjukkan bahwa nilai Sig (2Tailed) variabel $\mathrm{X} 1$ (persepsi atas resiko) sebesar 0,086, nilai Sig (2Tailed) variabel X2 (modal investasi minimal) sebesar 0,075, dan nilai Sig (2-Tailed) variabel Y (minat investasi di pasar modal) sebesar 0,174. Hal tersebut menunjukkan bahwa nilai Sig (2-Tailed) masing-masing variabel $>$ dari Level of Significant $(0,05)$, sehingga dapat disimpulkan bahwa variabel persepsi atas resiko, modal investasi minimal dan minat berinvestasi di pasar modal berdistribusi normal.

Hasil uji multikolinieritas menunjukkan bahwa variabel persepsi atas resiko dan modal investasi minimal memiliki nilai VIF di bawah 10 dan nilai Tolerance di atas 0,10. Ini berarti tidak terjadi multikolinearitas antara variabel persepsi atas resiko dan modal investasi minimal.

Hasil pengujian heteroskedastisitas pada Gambar 2 menunjukkan bahwa hasil pengolahan data diagram scatterplot menunjukkan penyebaran titik-titik yang menyebar (tidak menempel), sehingga bisa disimpulkan bahwa model tidak mempunyai masalah heteroskedastisitas.

Tabel 1. Hasil Uji Normalitas dan Uji Multikolinieritas

\begin{tabular}{lcc}
\hline Keterangan & Indikator & \\
\hline Uji Normalitas & Sig (2-tailed) $\mathrm{X}_{1}$ & 0,086 \\
& Sig (2-tailed) $\mathrm{X}_{2}$ & 0,075 \\
& Sig (2-tailed) $\mathrm{X}_{3}$ & 0,174 \\
\hline Uji Multikolinieritas & Tolerance $\mathrm{X}_{1}$ & 0,990 \\
& Tolerance X $_{2}$ & 0,990 \\
& VIP X X $_{1}$ & 1,001 \\
& VIP X $_{2}$ & 1,001 \\
\hline
\end{tabular}


Tabel 2. Hasil Analisis Regresi Berganda

\begin{tabular}{llccccc}
\hline & & \multicolumn{2}{c}{$\begin{array}{c}\text { Unstandardized } \\
\text { Coefficients }\end{array}$} & $\begin{array}{c}\text { Standardized } \\
\text { Coefficients }\end{array}$ & & \\
\cline { 2 - 5 } Model & $\mathrm{B}$ & Std. Error & Beta & $\mathrm{t}$ & Sig. \\
\hline 1 (Constant) & 16.922 & 2,889 & & 5,857 & 0,000 \\
& Risiko & 0,747 & 0,123 & 0,546 & 6,083 & 0,000 \\
Modal Investasi Minimal & $-0,458$ & 0,177 & $-0,232$ & $-2,584$ & 0,012 \\
\hline
\end{tabular}

1. Dependent Variable: Minat Investasi

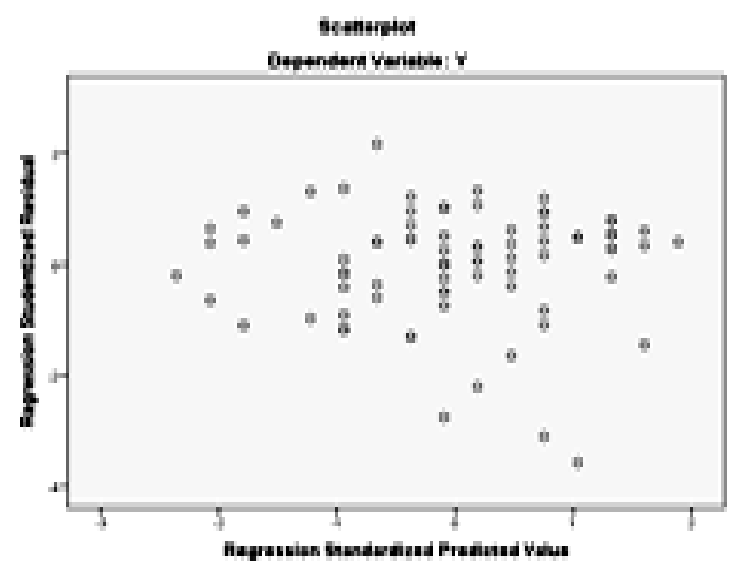

Gambar 1. Diagram Scatterplot Uji Heterokedastisitas

Pengujian hipotesis pertama dilakukan untuk mengetahui pengaruh persepsi atas resiko terhadap minat berinvestasi di pasar modal. Hasil pengujian dengan analisis regresi linier berganda pada Tabel 3 menunjukkan nilai signifikansi (Sig.t) variabel persepsi atas resiko sebesar 0,000 lebih kecil dari $\mathrm{a}=(0,05)$ dengan koefisien regresi sebesar 0,747 bertanda positif, yang artinya persepsi atas resiko berpengaruh positif pada minat mahasiswa berinvestasi di pasar modal, sehingga H1 diterima. Biasanya orang yang akan berinvestasi menghindari resiko. Namun dalam penelitian ini diperoleh hasil bahwa semakin tinggi resiko yang diterima, minat berinvestasi mahasiswa semakin besar. Hal ini kemungkinan disebabkan oleh mahasiswa yang menjadi sampel dalam penelitian ini sudah memiliki pengetahuan yang cukup mengenai pasar modal, dimana untuk memperoleh hasil yang tinggi harus disertai dengan resiko yang tinggi pula. Mahasiswa lebih tertarik melihat return (pengembalian) yang ditawarkan, sehingga persepsi mereka atas resiko juga tinggi. Hasil penelitian ini didukung oleh penelitian Malik (2017) yang menyatakan bahwa semakin tinggi resiko maka minat investor untuk berinvestasi semakin meningkat.

Pengujian hipotesis kedua dilakukan untuk mengetahui pengaruh modal investasi minimal terhadap minat berinvestasi di pasar modal. Hasil pengujian pada analisis regresi linier berganda pada Tabel 3 menunjukkan nilai signifikansi (Sig.t) variabel modal investasi minimal sebesar 0,012 lebih kecil dari $\mathrm{a}=$ $(0,05)$, dengan koefisien regresi 
sebesar $-0,458$ bertanda negative. Hal ini berarti modal investasi minimal berpengaruh negatif terhadap minat berinvestasi di pasar modal. Semakin kecil modal investasi minimal yang ditetapkan, maka minat mahasiswa untuk berinvestasi di pasar modal semakin besar. Mungkin banyak mahasiswa yang awalnya berminat untuk berinvestasi di pasar modal. Namun saat mengetahui modal investasi minimal yang diperlukan untuk membuka rekening efek mencapai jutaan rupiah, beberapa minat dari mahasiswa akan menghilang, karena sebagian besar mahasiswa menilai uang dalam nominal jutaan rupiah adalah nominal yang besar. Oleh karena itu saat modal investasi minimal ditetapkan dalam jumlah yang lebih rendah, minat mahasiswa untuk berinvestasi di pasar modal menjadi semakin tinggi.

Dengan modal investasi minimal yang terjangkau, mahasiswa bisa membuka rekening efek tanpa perlu modal yang banyak, mengingat sebagian besar mahasiswa belum memiliki penghasilan. Mahasiswa yang sudah bisa membuka rekening efek pada salah satu sekuritas, sudah bisa mulai melakukan transaksi di pasar modal. Hasil penelitian ini didukung oleh penelitian Nisa dan Sulaika (2017) menyatakan bahwa modal minimal yang ditetapkan memiliki pengaruh terhadap minat mahasiswa untuk berinvestasi di pasar modal.

\section{KESIMPULAN, IMPLIKASI DAN KETERBATASAN PENELITIAN}

Berdasarkan pembahasan yang telah diuraikan sebelumnya, maka dapat disimpulan bahwa:

1. Persepsi atas resiko berpengaruh positif terhadap minat berinvestasi di pasar modal dengan nilai signifikansi sebesar 0,000

2. Modal investasi minimal berpengaruh negatif terhadap minat berinvestasi di pasar modal dengan nilai signifikansi sebesar 0,012.

Penelitian ini terbatas pada penggunaan variabel persepsi atas resiko dan modal investasi minimal yang mempengaruhi minat berinvestasi di pasar modal. Penelitian berikutnya diharapkan dapat menggunakan variabel lain, seperti tingkat pengembalian yang diharapkan, pengetahuan yang dimiliki, dan lain-lain. Penelitian ini juga diharapkan dapat memberikan implikasi bagi pemerintah melalui Bursa Efek Indonesia agar semakin meningkatkan kegiatan-kegiatan termasuk pelatihan yang berkaitan dengan pasar modal, tidak hanya di 
kalangan mahasiswa tapi juga di masyarakat umum, agar masyarakat umum mulai memahami keuntungan yang bisa diperoleh jika melakukan investasi di pasar modal.

\section{REFERENSI}

Alleyne, P. dan Broome, T. 2011. Using the Theory of Planned Behaviour and Risk Propensity to Measure Investment Intentions among Future Investors. Journal of Eastern Caribbean Studies. 36 (1): 1-20

Anoraga, P. dan Pakarti. 2003. Pengantar Pasar Modal. Edisi Revisi. Jakarta: PT Rineka Cipta.

Darmadji, T. dan Fakhruddin. 2001. Pasar Modal di Indonesia Pendekatan Tanya Jawab. Jakarta: Salemba Empat.

Fahriani, D. 2012. Pengaruh Motivasi Terhadap Minat Mahasiswa Akuntansi untuk Mengikuti Pendidikan Profesi Akuntansi (PPAk). Jurnal Ilmu dan Riset Akuntansi. 1 (12): 1-22.

Herve, D. B. dan Yao, S. 2011. Management of Stock Price and It Effect on Economic Growth: Case Study of West African Financial Markets. International Journal of Business and Management. 6 (2): 52-71.

Jogiyanto. 2010. Teori Portofolio dan Analisis Investasi. Edisi Ketujuh. Yogyakarta: BPFE-Yogyakarta.

Kusmawati. 2011. Pengaruh Motivasi terhadap Minat Berinvestasi di Pasar Modal dengan Pemahaman Investasi dan Usia sebagai Variabel Moderat. Jurnal Ekonomi dan Informasi
Akuntansi (JENIUS). 1 (2): 103117.

Malik, A.D. 2017. Analisa FaktorFaktor yang Mempengaruhi Minat Masyarakat Berinvestasi di Pasar Modal Syariah melalui Bursa Galeri Investasi UISI. Jurnal Ekonomi dan Bisnis Islam. 3 (1): 61-84.

Merawati, L.K. dan Putra, M. 2015. Kemampuan Pelatihan Pasar Modal Memoderasi Pengaruh Pengetahuan Investasi dan Penghasilan pada Minat Berinvestasi Mahasiswa. Jurnal Ilmiah Akuntansi dan Bisnis. 10 (2): 105-118.

Nisa, A. dan Zulaika, L. 2017. Pengaruh Pemahaman Investasi, Modal Minimal Investasi dan Motivasi Terhadap Minat Mahasiswa Berinvestasi di Pasar Modal. Jurnal PETA. 2 (2): 22-35.

Raditya, D. Budiartha. dan Suardhika, S. 2014. Pengaruh Modal Investasi Minimal di BNI Sekuritas, Return dan Persepsi terhadap Resiko pada Minat Investasi Mahasiswa, dengan Penghasilan sebagai Variabel Moderasi. E-Jurnal Ekonomi dan Bisnis Universitas Udayana. 3 (7): 377-390.

Rappaport, A. 2005. The Economic of Short-Term Performance Obsession. Financial Analysts Journal, 61(3): 65.

Ravichandran. Thirunavukarasu. Nallaswamy. dan Babu. 2005. Estimation or Return on Investment in Share Market Through Ann. Jurnal of Theoretical and Applied Information Thecnology.

Republik Indonesia. 1995. UU Pasar Modal No 8 Tahun 1995. 
Riyadi, A. 2016. Analisis Faktor-Faktor yang Mempengaruhi Minat Mahasiswa untuk Berinvestasi di Pasar Modal (Studi pada Mahasiswa Fakultas Ekonomi dan Bisnis Islam UIN Sunan Kalijaga Yogyakarta). Skripsi. Yogyakarta: Universitas Islam Negeri Sunan Kalijaga.

Rosyidah, S. M. dan Lestari, W. 2013. Religiusitas Persepsi Resiko dalam Pengambilan Keputusan Investasi pada Perspektif Gender. Journal Business and Banking. 3 (2): 189-200.

Stoner, et al. 1995. Manajemen, 6 ed. Jakarta.

Sugiyono. 2009. Metode Penelitian Bisnis. Bandung: CV. Alfabeta.

Suharli, M. 2005. Studi Empiris Terhadap Dua Faktor yang Mempengaruhi Return Saham pada Industri Food \& Beverages di Bursa Efek Jakarta. Jurnal Akuntansi dan Keuangan, 7(2): 99-116.

Sunariyah. 2004. Pengantar Pengetahuan Pasar Modal. Edisi keempat. Yogyakarta: UPP AMP YKPN.

Tandelilin, E. 2003. Risiko Sistematik (Beta): Berbagai Isu Pengestimasian dan Keterterapannya dalam Penelitian dan Praktik. Pidato Pengukuhan Jabatan Guru Besar. Yogyakarta: Universitas Gadjah Mada.

Tandio, T. dan Widanaputra. 2016. Pengaruh Pelatihan Pasar Modal, Return, Persepsi Risiko, Gender, dan Kemajuan Teknologi pada Minat Investasi Mahasiswa. Ejurnal Akuntansi Universitas Udayana. 16 (3): 2316-2341.
Utomo, W. 2007. Analisis Pengaruh Beta dan Varian Return Saham Terhadap Return Saham. Tesis. Semarang: Program Pasca Sarjana, Universitas Diponogoro. 